\title{
Essential Oil Composition and Antibacterial Activity of Agrimonia Pilosa Ledeb (Rosaceae)
}

\author{
D.S. DHAMI ${ }^{1 *}$, G.C. SHAH ${ }^{1}$, VINOD KUMAR ${ }^{1}$, \\ YOGESH JOSHI $^{2}$, MANISH TRIPATHI ${ }^{2}$ and M. BISHT ${ }^{1}$
}

${ }^{1}$ Department of Chemistry, Kumaun University, Campus Almora-263601, Uttarakhand, India

${ }^{2}$ Department of Botany, Kumaun University, Campus Almora-263601, Uttarakhand, India devendra.dhami08@rediffmail.com

Received 21 February 2018 / Accepted 12 March 2018

\begin{abstract}
Essential oil composition of the aerial parts of Agrimonia pilosa Ledeb growing wild in the central Himalayan region of Uttarakhand, India was analyzed by capillary gas chromatography (GC-FID) and gas chromatography-mass spectrometry (GC-MS). A total of 15 constituents were identified, representing $95.29 \%$ of the oil composition. The oil consisted mainly of oxygenated monoterpenes $(75.74 \%)$ followed by monoterpene hydrocarbons $(18.68 \%)$. Major constituents identified were methyl myrtenate (71.39\%), limonene (11.86\%), $\alpha$-thujone (5.66\%) and myrtenyl acetate $(3.14 \%)$. The essential oil showed a broad spectrum of antibacterial activity against both the human and plant pathogenic bacteria. Oil showed the highest activity against human pathogenic bacteria $K$. pneumonia $(7.33 \mathrm{~mm}$, MIC $175 \mu \mathrm{L} / \mathrm{mL})$ and $P$. aeruginosa $(7.00 \mathrm{~mm}$, MIC 175 $\mu \mathrm{L} / \mathrm{mL})$. Plant pathogenic bacteria $R$. solanacearum $(6.70 \mathrm{~mm}$, MIC $175 \mu \mathrm{L} / \mathrm{mL})$ was found less resistant against the oil. The results showed that oil containing methyl myrtenate a major constituent has potential for treatment of infections caused by these pathogenic bacterial strains.
\end{abstract}

Keywords: Rosaceae, Agrimonia pilosa Ledeb, Essential oil, Antibacterial activity, Methyl myrtenate.

\section{Introduction}

The genus Agrimonia, family Rosaceae having pinnate leaves and yellow flowers followed by bristly fruits is found chiefly in north temperate regions. The species of Agrimonia belonging to the Rosaceae, are listed in the oriental medicine as an astringent hemostatic to treat bleeding, curing disorders related to the liver and bile, gastrointestinal and respiratory tract in traditional Austrian medicine ${ }^{1}$. Many pharmacological studies have reported that Agrimonia pilosa Ledeb showed broad biological properties, such as antioxidant activity, anti-viral effect and acetylcholinesterase inhibitory effect ${ }^{2-4}$. A. pilosa contains abundant flavonoids viz. catechin, hyperoside, quercitrin, quercetin and rutin. These compounds are demonstrated to be the major bioactive constituents having anti-inflammatory, anti-tumor, anti-virus, anti-bacteria and anti-oxidation functions ${ }^{5}$. Over the last two decades several 
research groups have reported the isolation of various biologically active compounds from this plant ${ }^{6-9}$. The major components in the essential oil of A. Aitchisonii were reported to be methyl myrtenate, limonene, linalool, myrtenyl acetate, linalyl acetate and zingiberene ${ }^{10,11}$. Essential oil from wild growing leaf and flower oil of Agrimonia eupatoria has been reported to possess $\beta$-caryophyllene, caryophyllene oxide, $\alpha$-humulene and $E$ - $\beta$-farnesene ${ }^{12}$. A.pilosa collected from three different locations of China contained hexadecanoic acid $(11.83-27.34 \%)$ as the main compound ${ }^{13}$.

To the best of our knowledge, there is no report on the essential oil composition and antibacterial activity of $A$. Pilosa from Uttrakhand, India. Therefore, this study was aimed to determine the antibacterial activity of $A$. Pilosa essential oil.

\section{Experimental}

The plant material was collected in the month of September (flowering stage) from Binsor forest (Almora District), Uttarakhand, India, at an altitude of 2700 meters. A voucher (specimen No. 116125) has been deposited at the Botanical Survey of India (BSI), Dehradun, India and Phytochemistry laboratory, Department of Chemistry, Almora, Kumaun University.

\section{Chemicals and reagents}

All chemicals and reagents used were of analytical grade. Mueller-Hinton broth (MHB) and Mueller-Hinton agar (MHA) were obtained from Hi-Media, India.

\section{Extraction of the essential oil}

Fresh aerial parts $(\sim 4 \mathrm{~kg})$ were subjected to steam distillation. The distillate obtained after steam distillation of fresh plant material was treated with $n$-hexane for the extraction of organic constituents. The distillate was further shaken with dichloromethane to ensure complete extraction of constituents. The $n$-hexane and dichloromethane extracts were combined and dried over anhydrous $\mathrm{Na}_{2} \mathrm{SO}_{4}$. Solvent was distilled off in a rotary vacuum evaporator (Perfit-RV 1240, Buchi type) to get residual oil which was stored at $\sim 4{ }^{\circ} \mathrm{C}$.

\section{GC-FID analysis}

A gas chromatographic analysis of essential oil was performed on a Shimadzu GC-2010 Ulta gas chromatograph equipped with flame ionization detector and a Rtx-5MS fused silica capillary column $(25 \mathrm{~m} \times 0.25 \mathrm{~mm}, 0.25 \mu \mathrm{m}$ film thickness). The injector and detector temperature were maintained at 260 and $270{ }^{\circ} \mathrm{C}$, respectively. Helium at a flow rate of 1.21 $\mathrm{mL} / \mathrm{min}$ and $69.0 \mathrm{kPa}$ inlet pressure was employed as the carrier gas. The oven temperature was programmed at $50{ }^{\circ} \mathrm{C}$ (first $2 \mathrm{~min}$ ), then increased at the rate: $3{ }^{\circ} \mathrm{C} / \mathrm{min}$ to $280{ }^{\circ} \mathrm{C}$, after which it was maintained at $280{ }^{\circ} \mathrm{C}$ for 18 minutes. The sample $(1.0 \mu \mathrm{L})$ was injected with 10:1 spilt ratio.

\section{GC-MS analysis}

GC-MS was carried out on Shimadzu GC-MS-QP2010 Ultra using identical oven temperature programming with following conditions: Rtx-5MS capillary column $(25 \mathrm{~m} \times$ $0.25 \mathrm{~mm}$, film thickness $0.25 \mu \mathrm{m}$ ); carrier gas: He (flow rate was $1.21 \mathrm{~mL} / \mathrm{min}$ ), injection in Split mode (10:1); injector temperature: $260{ }^{\circ} \mathrm{C}$. The MS was used in the electron impact (EI) conditions $(70 \mathrm{eV})$, ion $230^{\circ} \mathrm{C}$, mass scan mode: $2.41 \mathrm{scan} /$ second, mass range: $40-650$ $\mathrm{m} / \mathrm{z}$; a $5 \%$ solution of oil in hexane $(1.0 \mu \mathrm{L})$ was injected. 
The identification of individual compound was carried out by the calculation of Retention Indices (RI) using homologous $\mathrm{C}_{8}-\mathrm{C}_{34}$ (Supplier- Restek's ISO 9001:2008) $n$ alkane series and a comparison with available mass spectral data (NIST 11, Wiley 8 and FFNSC 2) and confirmed by comparison of their retention indices with those of reported in the literature ${ }^{14}$. For quantification purposes, relative area percentages obtained by FID were used without the use of correction factors.

\section{Antimicrobial screening of essential oils}

\section{Pathogenic bacterial strains}

The in vitro antibacterial activity was evaluated against five human pathogenic bacterial strains Bacillus subtilis (MTCC No. 441), Escherichia coli (MTCC No. 443), Klebsiella pneumoniae (MTCC No. 3384), Pseudomonas aeruginosa (MTCC No. 424), Salmonella typhimurium (MTCC No. 3224) and six plant pathogenic bacterial strains Agrobacterium tumefaciens (MTCC No. 609), Erwinia crysanthemi (KUMSCC 328), Ralstonia solanacearum (BI0012), Xanthomonas campestris (BB0006), X. oryzae (BH0007) and X. phaseoli (KUMSCC 327)]. Some of the test strains were purchased from Indian Type Culture Collection (ITCC), ICAR, New Delhi and some provided by the Department of Biotechnology, Bhimtal, Kumaun University, which were procured from the Institute of Microbial Technology, Chandigarh. Indian Type Culture Collection (ITCC) and Microbial Technology Culture Collection (MTCC) numbers represent the standard strain numbers assigned to these microorganisms. The cultures of bacteria were maintained throughout the experiment at $4^{\circ} \mathrm{C}$ on their appropriate nutrient agar and used as stock cultures.

\section{Antimicrobial activity by disc-diffusion method}

Evaluation of antimicrobial activity of essential oil samples was done by disc-diffusion method described by Clinical and Laboratory Standards Institute ${ }^{15}$. The samples were dissolved in dimethyl sulphoxide (DMSO) to prepare desired concentrations. Inoculums of the microbial strains $\left(1 \times 10^{6} \mathrm{CFU} / \mathrm{mL}\right)$ were plated using sterile swabs into petri dishes $(90 \mathrm{~mm})$ with $20 \mathrm{~mL}$ of Nutrient Agar, and then discs of Whatman paper-42 were soaked in sample solution $(15 \mu \mathrm{L} / \mathrm{mL})$ and placed onto inoculated petri dishes. Standard antibiotic streptomycin $(15 \mathrm{mg} / \mathrm{mL})$ was used as a positive control and DMSO as negative control. The petri dishes were pre-incubated for $3 \mathrm{~h}$ at room temperature, allowing the complete diffusion of the samples and then, incubated at $37 \pm 1{ }^{\circ} \mathrm{C}$ for 24 $\mathrm{h}^{16}$. Finally the zones of inhibition were measured.

\section{Antimicrobial activity by broth dilution method}

The evaluation of MICs was done using the agar dilution method with slight modifications described by the National Committee for Clinical Laboratory Standards ${ }^{17}$. Equal volumes of each microbial strain culture, containing approximately $1 \times 10^{6}$ $\mathrm{CFU} / \mathrm{ml}$, were applied onto MHB supplemented with the essential oil at concentration ranging from $25-250 \mu \mathrm{l} / \mathrm{ml}$ in tubes. These cultures were then incubated at $37^{\circ} \mathrm{C}$ for 24 hrs and then the cultures were finally inoculated on nutrient agar media to determine the growth of bacteria. Controls of bacteria without the oil were also applied. The concentration at which no visible growth was observed is considered as MICs.

Statistical analysis

Mean value \pm SD was determined by using XLSTAT 14 statistical computer software package. 


\section{Results and Discussion}

The essential oil (yield $0.1 \%$; v/w) obtained from aerial parts of $A$. pilosa was analyzed by using GC-FID and GC-MS. A total of 15 constituents, representing $95.29 \%$ of the total oil have been identified. The retention index of volatile compounds $\left(\mathrm{RI}^{\mathrm{a}}\right.$ and $\left.\mathrm{RI}^{\mathrm{b}}\right)$ and their percentage are summarized in Table 1. Essential oil showed the dominant presence of oxygenated monoterpenes $(75.74 \%)$ followed by monoterpene hydrocarbons $(18.68 \%)$. The sesquiterpene hydrocarbons accounted only for $0.87 \%$. The essential oil has been characterized by a high amount of methyl myrtenate $(71.39 \%)$. The other major components are limonene $(11.86 \%)$, $\alpha$-thujone $(5.66 \%)$ and myrtenyl acetate $(3.14 \%)$. Previous report of A. Pilosa collected from different regions of China was characterised by the presence of hexadecanoic acid $(11.83-27.34 \%)$ as main constituent ${ }^{13}$ while in present study, oil was rich in methyl myrtenate $(71.39 \%)$ with absence of hexadecanoic acid. Chemical variation of essential oil may be attributed due to influences of environmental, genetic and ecological factors such as light and temperature ${ }^{18-24}$.

Table 1. Chemical composition of essential oil from Agrimonia pilosa

\begin{tabular}{|c|c|c|c|c|c|}
\hline S. No. & Compound & $\mathrm{RI}^{\mathrm{a}}$ & $\mathrm{RI}^{\mathrm{b}}$ & $\begin{array}{c}\% \\
\text { Composition } \\
\end{array}$ & $\begin{array}{c}\text { Method of } \\
\text { identification }\end{array}$ \\
\hline 1. & $\alpha$-Thujone & 932 & 930 & 5.66 & $\mathrm{c}$ \\
\hline 2. & Camphene & 957 & 954 & 0.18 & $\mathrm{c}$ \\
\hline 3. & $\beta$-Pinene & 979 & 979 & 0.83 & $\mathrm{c}$ \\
\hline 4. & Myrcene & 991 & 990 & 0.15 & $\mathrm{c}$ \\
\hline 5. & Limonene & 1031 & 1029 & 11.86 & $\mathrm{c}$ \\
\hline 6. & Linalool & 1101 & 1096 & 0.27 & $\mathrm{c}$ \\
\hline 7. & $\alpha$-Campholenal & 1128 & 1126 & 0.13 & $\mathrm{c}$ \\
\hline 8. & trans - Verbenol & 1147 & 1144 & 0.12 & $\mathrm{c}$ \\
\hline 9. & Myrtenal & 1199 & 1195 & 0.26 & $\mathrm{c}$ \\
\hline 10. & Linalool acetate & 1259 & 1257 & 0.25 & $\mathrm{c}$ \\
\hline 11. & Methyl myrtenate & 1300 & 1294 & 71.39 & $\mathrm{c}$ \\
\hline 12. & Myrtenyl acetate & 1329 & 1326 & 3.14 & $\mathrm{c}$ \\
\hline 13. & Methyl perrilate & 1396 & 1393 & 0.18 & $\mathrm{c}$ \\
\hline 14. & $\alpha$-Zingiberene & 1493 & 1493 & 0.72 & $\mathrm{c}$ \\
\hline \multirow[t]{7}{*}{15.} & $E, E, \alpha$-Farnesene & 1508 & 1505 & 0.15 & $\mathrm{c}$ \\
\hline & Total identified & & & $95.29 \%$ & \\
\hline & $\begin{array}{l}\text { Monoterpene } \\
\text { hydrocarbones }\end{array}$ & & & $18.68 \%$ & \\
\hline & $\begin{array}{l}\text { Oxygenated } \\
\text { monoterpenes }\end{array}$ & & & $75.74 \%$ & \\
\hline & $\begin{array}{l}\text { Sesquiterpene } \\
\text { hydrocarbones }\end{array}$ & & & $0.87 \%$ & \\
\hline & Total unidentified & & & $4.71 \%$ & \\
\hline & Oil yield $(\%, \mathrm{v} / \mathrm{w})$ & & & 0.11 & \\
\hline
\end{tabular}

${ }^{a}$ Retention index (RI) calculated relative to homologous series of n-alkanes $\left(C_{8^{-}} C_{24}\right)$ on Rtx-5 nonpolar fused silica capillary column; ${ }^{b}$ Retention index (RI) Adams; ${ }^{c} M S$, NIST and WILEY libraries spectra and the literature 
Essential oil of A. pilosa was tested against five human and six plant pathogenic bacteria. Results presented in Table 2 showed that oil exhibited different antibacterial activity against both the tested bacterial strains. The oil showed the maximum activity against human bacterial strain K. pneumonia $(7.33 \mathrm{~mm}$, MIC $175 \mu \mathrm{L} / \mathrm{mL})$ followed by $P$. aeruginosa $(7.00 \mathrm{~mm}$, MIC $175 \mu \mathrm{L} / \mathrm{mL})$ and S. typhimurium $(6.66 \mathrm{~mm}$, MIC $200 \mu \mathrm{L} / \mathrm{mL})$ while Modest activity was observed against E. coli $(5.00 \mathrm{~mm}$, MIC $200 \mu \mathrm{L} / \mathrm{mL})$. The order of resistivity of human pathogenic bacteria against oil was found E. coli $>$ B. subtilis $>S$. typhimurium $>P$. aeruginosa $>K$. pneumonia. The oil demonstrated significant activity against plant pathogenic bacteria. The result showed highest antibacterial activity against $R$. solanacearum $(6.75 \mathrm{~mm}$, MIC $175 \mu \mathrm{L} / \mathrm{mL})$. The A. pilosa was found to be less active to the control of $X$. phaseoli $(5.50 \mathrm{~mm})$ and $X$. oryzae $(5.00 \mathrm{~mm})$ at $250 \mu \mathrm{L} / \mathrm{mL}$ MIC value. The order of resistivity of plant pathogenic bacteria against oil was found $X$. oryzae $>X$. phaseoli $>X$. campestris $>$ A. tumefaciens $>E$. crysanthemi $>R$. solanacearum. Based on the zone of inhibition and minimum inhibitory concentrations (MIC) values $K$. pneumonia and $R$. solanacearum were the most sensitive strains tested to the oil. While E. coli and $X$. oryzae were the most resistant towards the oil. As compared to the standard antibiotic (streptomycin) oil showed significant activity against all the tested bacteria. The activity of the oil may be due to the presence of higher percentage of methyl myrtenate a oxygenated monoterpene and the synergetic effect of other major and minor compounds present in the oil.

Table 2. Antibacterial activity of the Agrimonia pilosa essential oil by disc-diffusion method

\begin{tabular}{ccccc}
\hline \multirow{2}{*}{ Bacterial strains } & \multicolumn{2}{c}{ Agrimonia pilosa } & \multicolumn{2}{c}{ Reference antibiotic } \\
\cline { 2 - 4 } & ZOI $(\text { mean } \pm \mathrm{SD})^{\mathrm{a}}$ & $\begin{array}{c}\mathrm{MIC} \\
(\mu \mathrm{L} / \mathrm{mL})\end{array}$ & ZOI (mean $\pm \mathrm{SD})^{\mathrm{b}}$ & $\begin{array}{c}\mathrm{MIC} \\
(\mathrm{mg} / \mathrm{mL})\end{array}$ \\
\hline Human Pathogenic & & & & \\
B. subtilis & $6.33 \pm 0.57$ & 200 & $26.33 \pm 0.57$ & 100 \\
E. coli & $5.00 \pm 0.33$ & 200 & $31.66 \pm 0.66$ & 50 \\
K. pneumoniae & $7.33 \pm 0.57$ & 175 & $30.33 \pm 0.57$ & 50 \\
P. aeruginosa & $7.00 \pm 0.15$ & 175 & $27.33 \pm 1.00$ & 75 \\
S. typhimurium & $6.66 \pm 0.57$ & 200 & $24.66 \pm 0.33$ & 100 \\
Plant pathogenic & & & & \\
A. tumefaciens & $6.00 \pm 0.57$ & 200 & $33.00 \pm 1.00$ & 50 \\
E. crysanthemi & $6.30 \pm 0.33$ & 200 & $25.66 \pm 0.57$ & 50 \\
R. solanacearum & $6.70 \pm 0.55$ & 175 & $25.66 \pm 0.57$ & 100 \\
X. campestris & $6.00 \pm 0.57$ & 225 & $23.66 \pm 0.52$ & 100 \\
X. oryzae & $5.00 \pm 1.00$ & 250 & $24.33 \pm 0.52$ & 100 \\
X. phaseoli & $5.50 \pm 0.50$ & 250 & $32.66 \pm 1.00$ & 50 \\
\hline
\end{tabular}

${ }^{a}$ Inhibition zone diameter includes Whatman paper-42 $(3 \mathrm{~mm})$ at $15 \mu \mathrm{L} / \mathrm{mL},{ }^{b}$ Inhibition zone diameter includes Whatman paper-42 (3 mm) at $15 \mathrm{mg} / \mathrm{mL}$

\section{Conclusion}

The essential oil composition and antibacterial activity of $A$. pilosa is being reported for the first time from Uttarakhand Himalayan region. The essential oil of aerial parts of A. pilosa containing methyl myrtenate as major constituents showed significant antibacterial activity against both the human and plant pathogenic bacteria. All the bacterial strains showed the sensitivity towards the essential oil, thus indicated the importance of this plant as natural agents for the treatment of infectious diseases caused by respective bacteria. 


\section{Acknowledgement}

The authors are thankful to Department of Chemistry, Kumaun University Campus Almora for providing laboratory facilities and Department of Botany, Kumaun University Campus Almora for bioactivity.

\section{References}

1. Vogl S, Picher P, Mihaly-Bison J, Fakhrudin N, Atanasov A G, Heiss E H, Wawrosch C, Reznicek G, Dirsch V M, Saukel J and Kopp B, J Ethnopharm., 2013, 149(3), 750-771; DOI:10.1016/j.jep.2013.06.007

2. Zhu L, Tan J, Wang B, He R, Liu Y and Zheng C H, Chem Biodivers., 2009, 6, 17161726; DOI:10.1002/cbdv.200800248

3. Shin W J, Lee K H, Park M H and Seong B L, Microbial Immunol., 2010, 54(1), 11-19; DOI:10.1111/j.1348-0421.2009.00173.x

4. Jung M and Park M, Molecules., 2007, 12(9), 2130-2139; DOI:10.3390/12092130

5. Jian J and Xia Q, Phytomedicine Effective Component Book. People's Hygiene Press, 1986, Beijing, China.

6. Pei Y H, Li X and Zhu T R, Yao Hsueh Pao., 1989, 24, 431-437.

7. Pei Y H, Li X, Zhu T R and Wu L J, Yao Xue Xue Bao., 1990, 25, 267-270.

8. Isao K, Naosuke B, Yumiko O and Nobusuke K, Phytochem., 1988, 27(1), 297-299; DOI:10.1016/0031-9422(88)80641-1

9. Su G, Su S and Zhu T, Shenyang Yaoxueyuan Xuebao., 1984, 1, 44-50.

10. Melkani A B, Negi A, Javed M S, Beuchamp P S and Dev V, J Essent Oil Res., 2007, 19(3), 273-275; DOI:10.1080/10412905.2007.9699278

11. Tiwari K, Pande C, Tewari G, Kunwar G and Punetha D, J Med Aromatic Plants., 2015, 6(1), 15-20.

12. Navaei M N and Mirza M A, J Essent Oil Bearing Plants., 2009, 12(3), 369-373; DOI:10.1080/0972060X.2009.10643733

13. Wang H, Liu Y, Wei S, Yan Z and Jin X, Chem Biodiverts, 2012, 9(3), 662-668; DOI:10.1002/cbdv.201100239

14. Adams R P, Identifiaction of Essential oil Components by Gas Chromatography/Mass Spectrometry, Allred Publishing Corporation, Carol stream IL, USA, 2007.

15. Clinical and Laboratory Standards Institute, Performances Standards for Antimicrobial Disk Susceptibility Tests, $10^{\text {th }}$ Ed., Approved standard. Document M02-A10, CLSI, Wayne Pa, 2009.

16. Das K, Tiwari R K S and Shrivastav D K, J Med Plants Res., 2010, 4(2), 104-111; DOI:10.5897/JMPR09.030

17. National Committee for Clinical Laboratory Standards, Methods for Dilution Antimicrobial Susceptibility Tests for Bacteria that Grow Aerobically. Approved Standards NCCLS Document M7-A5. NCCLS, Wayne Pa, 2001.

18. Loziene K and Venskuitonis P R, Biochem Syst Ecol., 2005, 33(5), 517-525; DOI:10.1016/j.bse.2004.10.004

19. Boira H and Balnquer A, Biochem Syst Ecol., 1998, 26(8), 811-822; DOI:10.1016/S0305-1978(98)00047-7

20. Salgueiro L R, Vila R, Tomas X, Tomi F, Canigueral S, Casanova J, Proenca da Cunha A and Adzet T, Phtochem., 1995, 38(2), 391-396; DOI:10.1016/00319422(94)00657-F 
21. Curado M A, Oliveira C B A, Jesus J G, Santos, S C, Seraphin J C and Ferri P H, Phytochem., 2006, 67(21), 2363-2369; DOI:10.1016/j.phytochem.2006.08.002

22. Robles C and Garzino S, Phytochem., 2000, 53(1), 71-75; DOI:10.1016/S00319422(99)00460-4

23. Burbott A J and Loomis W D, Plan Physiol., 1967, 42(1), 20-28; DOI: $10.1104 / p p .42 .1 .20$

24. Clark R J and Menary R C, Aust J Plant Physiol., 1980, 7, 693-697. 